\title{
EFFECT OF SODIUM CHLORIDE ON PRODUCTION AND TOXICITY OF EXTRACELLULAR PRODUCTS OF EDWARDSIELLA TARDA
}

\author{
EBTSAM SAYED HASSAN *; MAHMOUD MOSTAFA MAHMOUD * and TOSHIHIRO NAKAI ** \\ ${ }^{*}$ Faculty of Veterinary Medicine, Assiut University, Assiut 71526, Egypt. \\ ** Graduate School of Biosphere Science, Hiroshima University, Hiroshima 739-8528, Japan. \\ Email: mahmoud88@hotmail.com
}

\section{ABSTRACT}

Received at: $25 / 9 / 2014$

The effect of $\mathrm{NaCl}$ concentration in the culture medium on the production and Accepted: 4/11/2014 toxicity of Edwardsiella tarda extracellular products (ECP) was studied. Edwardsiella tarda (FK1051) was cultured in a peptone-yeast extract broth supplemented with $3 \% \mathrm{NaCl}(3 \%-\mathrm{NaCl}$ culture) and without $\mathrm{NaCl}(0 \%-\mathrm{NaCl}$ culture). The ECP of both cultures were prepared by the cellophane plate method. The wet bacterial weights and the protein concentrations were detected at different time intervals. The bacterial weights decreased after 2-3 days incubation and thereafter the ECP protein levels increased. The protein concentration in ECP of $3 \%-\mathrm{NaCl}$ culture was higher than that of $0 \%-\mathrm{NaCl}$ culture. SDS-PAGE revealed the appearance of new bands (35 and $70 \mathrm{kDa}$ ) and intensification of other bands in the ECP of $3 \%-\mathrm{NaCl}$ culture. The intramuscular injection of ECP in goldfish revealed higher toxicity in the $3 \%-\mathrm{NaCl}$ culture. These results suggest that the $\mathrm{NaCl}$-induced ECP toxicity of E. tarda may play a vital role in its virulence.

Key words: Sodium chloride, Extracellular products, Toxicity, Edwardsiella tarda

\section{INTRODUCTION}

Edwarsiella tarda as a member of family enterobacteriaceae has a wide host range including not only fish but also reptiles, amphibians and mammals (Evance et al., 2011). E. tarda infection (edwardsiellosis) leads to extensive losses in many commercially important freshwater and marine fish such as Nile tilapia Oreochromis niloticus (Badran, 1993; Galal et al., 2005 and Ibrahem et al., 2011), channel catfish Ictalurus punctatus, Japanese eel Anguilla japonica, carp Cyprinus carpio, goldfish Carassius auratus, mullet Mugil cephalus, Chinook salmon Oncorhynchus tshawytscha, Japanese flounder Paralichthys olivaceus, and striped bass Morone saxatilis and others (Evance et al., 2011).

Though the exact pathogenic mechanism of this bacterium is still not clearly explained, some virulence factors have been proposed including Type III and Type IV secretion systems, invasion of epithelial cells, resistance to serum and production of toxins (Ullah and Arai, 1983; Suprapto et al., 1995; Ling et al., 2000; Sirinivasa Rao et al., 2001 and Leung et al., 2012).

Extracellular products (ECP) of many fish pathogens include substances such as enzymes and proteins that exhibit toxicity to fish. For example, Aeromonas hydrophila produces hemolytic and proteolytic exotoxins lethal to Nile tilapia Oreochromis niloticus (Khalil and Mansour, 1997). Vibrio splendidus-Vibrio lentus related group also produces proteolytic enzyme as one of its ECP (Farto et al., 2006). Besides, Vibrio anguillarum ECP elicited lethal toxicity against goldfish, Japanese eel, ayu Plecoglossus altivelis and mouse and this toxic effect was attributed to the possession of proteolytic enzyme (Inamura et al., 1984). The most potent lethal neurotoxin (acetylcholinestrase) was determined in ECP of 42 strains of the family vibrionaceae including fishpathogenic $V$. anguillarum (Pérez et al., 1998). Cytotoxic effect for fish cell lines was also reported to be induced by the ECP of V. damselae (Wang et al., 1998). Balb/c mice, injected with ECP of $A$. salmonicida subsp. achromogenes, displayed symptoms similar to toxic shock syndrome (Gudmundsdóttir and Gudmundsdóttir, 2001).

In Edwardsiella tarda, the ECP has been considered a virulence factor. Ullah and Arai (1983) demonstrated the dermatotoxic effect of E. tarda when injected into rabbits. ECP toxicity to Japanese eel and Japanese flounder was verified (Suprapto et al., 1995). Subsequently, the lethal toxin of $E$. tarda was purified and proved to be a protein with $37 \mathrm{kDa}$ molecular weight (Suprapto et al., 1996).

Previously, both hemagglutinating activity (HA) and adhesion of E. tarda were found to be induced by the 
high $\mathrm{NaCl}$ in the culture medium (Mahmoud et al., 2006; Yasunobu et al., 2006). The objective of the present study is to investigate the effect of $\mathrm{NaCl}$ concentration on the production and toxicity of the ECP.

\section{MATERIALS and METHODS}

\section{Bacterial strain and culture conditions:}

E. tarda (FK1051), isolated from diseased Japanese flounder was used. The bacteria were pre-cultured on Trypto-Soya Agar (TSA, Nissui) at $25^{\circ} \mathrm{C}$ for $24 \mathrm{~h}$.

Following the method described before (Yasunobu et al., 2006), E. tarda was inoculated into $10 \mathrm{~mL}$ of a liquid medium consisted of $1 \%$ peptone- $0.5 \%$ yeast extract ( $\mathrm{pH}$ 6.5). The bacterial suspension was diluted 100 -fold in the same medium, and then $100 \mu \mathrm{L}$ of the dilution was inoculated into $10 \mathrm{~mL}$ of the liquid medium supplemented with $3 \% \mathrm{NaCl}$ or without $\mathrm{NaCl}$. The bacterial culture was incubated at $25^{\circ} \mathrm{C}$ overnight with shaking $(100 \mathrm{rpm})$ and the bacterial cells were harvested by centrifugation $(5,000 \times g, 10$ min). The bacterial cells were washed twice with phosphate buffered saline (PBS, $\mathrm{pH} 7.4)$ and the cell concentration was adjusted to $\mathrm{A}_{530}=1.0$ (ca. $10^{9}$ $\mathrm{CFU} / \mathrm{mL}$ ).

\section{Preparation of ECP:}

The ECP was prepared by the cellophane plate method (Liu, 1957). Cellophane was cut to fit the bottom of petri dish and then was sterilized by autoclaving $\left(121^{\circ} \mathrm{C}, 15 \mathrm{~min}\right)$ and overlaid on peptoneyeast agar medium (1\% peptone- $0.5 \%$ yeast extract and $1.5 \%$ agar) supplemented with $3 \% \mathrm{NaCl}$ or without $(0 \%) \mathrm{NaCl}$. Each cellophane-overlaid agar plate was inoculated with $200 \mu \mathrm{L}$ (approximately 1 $\mathrm{mg} /$ plate; $10^{9} \mathrm{CFU} / \mathrm{mL}$ ) of the pre-cultured bacteria either in the medium containing $3 \%$ - or $0 \%-\mathrm{NaCl}$. The cultures were incubated at $25^{\circ} \mathrm{C}$ for 13 days. This culture technique allows the bacteria to draw nutrients freely from the medium beneath the cellophane sheet, and at the same time prevent mixing of the ECP proteins released by the bacteria with the proteins present in the underlying culture medium.

Bacterial cells cultured on both $0 \%-$ and $3 \%-\mathrm{NaCl}$ cellophane-overlaid agar were harvested with $2 \mathrm{~mL}$ of PBS (pH 7.4) per each plate. The cell suspensions were centrifuged at $12,000 \times \mathrm{g}$ at $4^{\circ} \mathrm{C}$ for $20 \mathrm{~min}$. The resultant supernatants containing ECP were sterilized by $0.45-\mu \mathrm{m}$ membrane syringe filters. The protein concentration of the supernatants was measured following the method of Bradford (1976) with bovine serum albumin as the standard.

\section{SDS-PAGE of the ECP:}

Sodium dodecyl sulphate polyacrylamide gel electrophoresis (SDS-PAGE) was performed according to the method of Laemmli (1970) using a
$10 \%$ acrylamide slab gel in presence of 2mercaptoethanol. The gel was stained with Coomassie brilliant blue.

Fish:

Goldfish Carassius auratus $(6 \pm 1 \mathrm{~g})$ were used for exploring the toxicity of ECP. The fish were acclimated for at least 2 weeks prior to the experiment. The aquaria were supplied with tap dechlorinated water and maintained at $25 \pm 1{ }^{\circ} \mathrm{C}$. The feeding was discontinued during the toxicity test.

\section{Toxicity test:}

The ECP were collected and pooled from the $0 \%$ - and $3 \%-\mathrm{NaCl}$ cultures at $9-13$ days post-incubation. Two groups of fish (10 fish/group) were injected intramuscularly with the ECP from $0 \%-\mathrm{NaCl}$ culture or $3 \%-\mathrm{NaCl}$ culture. Fish received $50 \mu \mathrm{L}(19 \mu \mathrm{g}$ protein/fish) of each ECP. Another group of 10 fish was injected with $50 \mu \mathrm{L}$ sterile PBS and served as a control group. The survival rate was calculated for 2 weeks.

\section{RESULTS}

\section{Preparation of ECP:}

The bacterial growth, represented by the wet bacterial weight, of the $0 \%-\mathrm{NaCl}$ culture was higher than that of the $3 \%-\mathrm{NaCl}$ culture. The bacterial growth in both cultures decreased gradually after 2-3 days incubation. On the contrary, the concentration of protein in ECP of $0 \%-\mathrm{NaCl}$ culture was lower than that of $3 \%-\mathrm{NaCl}$ culture. The protein concentration of the ECP of $0 \%$ $\mathrm{NaCl}$ culture could be detected only 9 days after incubation at $25^{\circ} \mathrm{C}$. Whereas, for ECP of $3 \%-\mathrm{NaCl}$ culture, the protein level was detectable from the third day after incubation. The protein concentration of $\mathrm{ECP}$ in the $3 \%-\mathrm{NaCl}$ culture reached its peak at 9 days post-incubation while that in $0 \%-\mathrm{NaCl}$ culture continuously increased until the end of experiment (Table 1, Fig. 1).

\section{SDS-PAGE of the ECP:}

SDS-PAGE analysis of the ECP showed differences in the composition and concentration of the ECP of $0 \%$ - and $3 \%-\mathrm{NaCl}$ cultures. At least 2 bands (about 35 and $70 \mathrm{kDa}$ ) were identified as being unique to the ECP of $3 \%-\mathrm{NaCl}$ culture. There were also differences in the staining intensity of several shared bands (Fig. 2).

\section{Toxicity test:}

The intramuscular injection of the pooled ECP of 3\%$\mathrm{NaCl}$ culture exhibited higher mortality (90\%) than that $(40 \%)$ displayed by the ECP of $0 \%-\mathrm{NaCl}$ culture (Table 2, Fig. 3). No mortalities were recorded in the fish injected with sterile PBS (control group). 
Table 1: Effect of $\mathrm{NaCl}$ concentration on bacterial growth and protein concentration of extracellular products (ECP) of $E$. tarda at different incubation periods.

\begin{tabular}{ccccc}
\hline \multirow{2}{*}{$\begin{array}{c}\text { Incubation period } \\
\text { (days) }\end{array}$} & \multicolumn{2}{c}{$0 \%-\mathrm{NaCl}$ culture } & \multicolumn{2}{c}{$3 \%-\mathrm{NaCl}$ culture } \\
\cline { 2 - 5 } & $\begin{array}{c}\text { Wet bacterial } \\
\text { weight }(\mathrm{g})\end{array}$ & $\begin{array}{c}\text { Protein conc. } \\
(\mathrm{mg} / \mathrm{mL})\end{array}$ & $\begin{array}{c}\text { Wet bacterial } \\
\text { weight }(\mathrm{g})\end{array}$ & $\begin{array}{c}\text { Protein conc. } \\
(\mathrm{mg} / \mathrm{mL})\end{array}$ \\
\hline 1 & 0.0497 & $\mathrm{UN}^{*}$ & 0.0216 & $\mathrm{UN}$ \\
2 & 0.0540 & $\mathrm{UN}$ & 0.0258 & $\mathrm{UN}$ \\
3 & 0.0448 & $\mathrm{UN}$ & 0.0269 & 0.03 \\
5 & 0.0426 & $\mathrm{UN}$ & 0.0218 & 0.06 \\
7 & 0.0417 & $\mathrm{UN}$ & 0.0187 & 0.30 \\
9 & 0.0396 & 0.27 & 0.0160 & 0.48 \\
11 & 0.0386 & 0.34 & 0.0135 & 0.45 \\
13 & 0.0339 & 0.55 & 0.0096 & 0.34 \\
\hline
\end{tabular}

*Undetectable

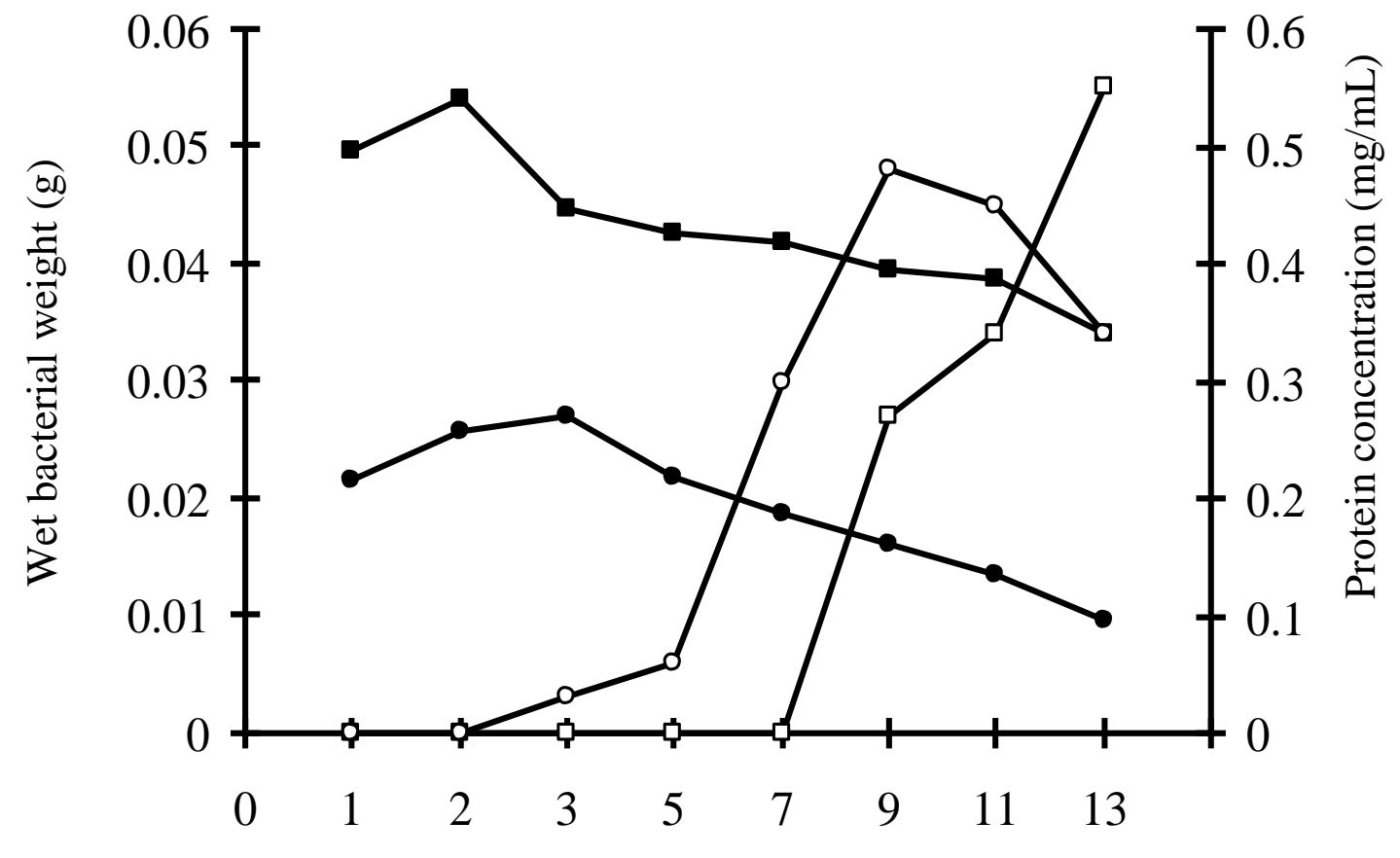

Incubation time (days)

Fig. 1: Effect of $\mathrm{NaCl}$ concentration on bacterial growth and protein concentration of extracellular products (ECP) of E. tarda at different incubation periods. Wet bacterial weight: $0 \%-\mathrm{NaCl}$ culture (a), $3 \%-\mathrm{NaCl}$ culture (•). ECP protein concentration: $0 \%-\mathrm{NaCl}$ culture $(\square), 3 \%-\mathrm{NaCl}$ culture $(\circ)$. 


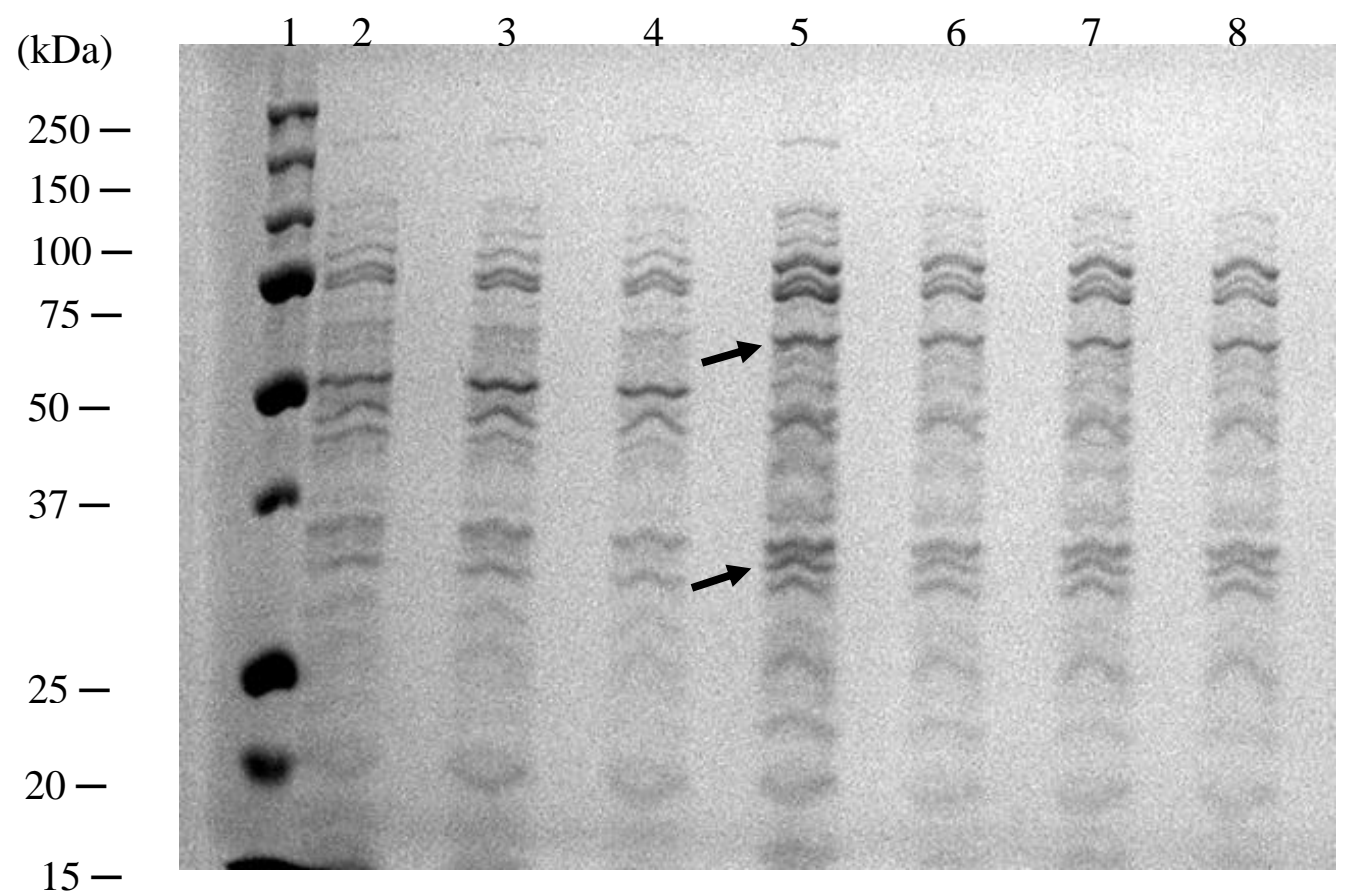

Fig. 2: SDS-PAGE of ECP of 0\%- and 3\%-NaCl cultures. Lane 1, molecular weight marker; lanes 2-4, ECP of $0 \%-\mathrm{NaCl}$ cultures at 9,11 and 13 days incubation, respectively; lanes 5-8, ECP of 3\%- $\mathrm{NaCl}$ cultures at 7, 9, 11 and 13 days incubation, respectively. Arrows refer to bands specific to ECP of the $3 \%-\mathrm{NaCl}$ culture. The gel was stained with Coomassie brilliant blue.

Table 2: Toxicity of the E. tarda extracellular products (ECP) to goldfish. A dose of $50 \mu \mathrm{L}$ (19 $\mu \mathrm{g}$ protein/fish) of ECP/ fish was injected intramuscularly and mortalities were recorded for 2 weeks

\begin{tabular}{ccc}
\hline $\mathrm{NaCl}$ concentration & $\begin{array}{c}\text { Mortality \% } \\
\text { (dead/tested) }\end{array}$ & Mean days to death \\
\hline $0 \%-\mathrm{NaCl}$ culture & $40(4 / 10)$ & 2 \\
$3 \%-\mathrm{NaCl}$ culture & $90(9 / 10)$ & 2 \\
Control & $0(0 / 10)$ & - \\
\hline
\end{tabular}

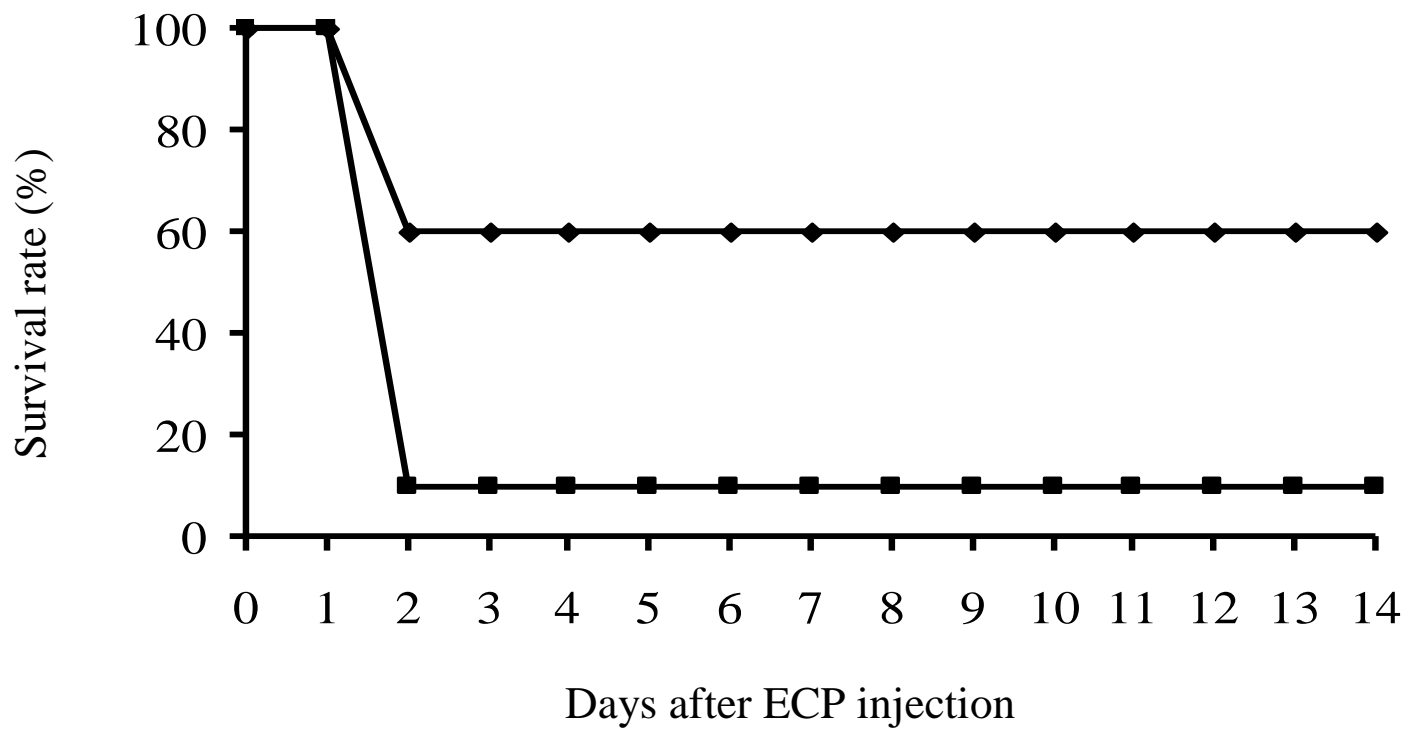

Fig. 3: Survival rate of goldfish injected intramuscularly with pooled E. tarda ECP. A dose of $50 \mu \mathrm{L}(19 \mu \mathrm{g}$ protein/fish) of ECP/fish was applied. ECP of $0 \%-\quad \mathrm{NaCl}$ culture ( $\bullet$ ) and of $3 \%-\mathrm{NaCl}$ culture (- $)$. 


\section{DISCUSSION}

ECP mostly consisted of enzymes that facilitate the propagation of infectious bacteria by causing extensive host tissue damage, thereby degrading host tissues to provide readily-available nutrients for bacterial growth. Furthermore, ECP counteract the host defense system by degrading immunoglobulins and components of the complement system. The involvement of ECP in the pathogenicity of E. tarda is currently not fully recognized. Some studies were previously conducted regarding the production of lethal toxins by E. tarda and their assumed role in the virulence of this pathogen (Ullah and Arai, 1983; Suprapto et al., 1995 and Han et al., 2006).

The present study investigated the influence of the increase in the $\mathrm{NaCl}$ concentration in the culture medium on the ability of E. tarda to produce ECP and its toxicity to fish. The culture at high $\mathrm{NaCl}$ $(3 \%-\mathrm{NaCl}$ culture) resulted in lowered bacterial growth indicating that the high salt condition is not optimal for its growth though E. tarda can grow in a medium supplemented with as much as $4 \% \mathrm{NaCl}$. However, the production of ECP was higher in 3\%$\mathrm{NaCl}$ culture than in $0 \%-\mathrm{NaCl}$ culture. The $\mathrm{NaCl}-$ promoted ECP production, in addition to the induced adhesion by high $\mathrm{NaCl}$ (Mahmoud et al., 2006), may help the E. tarda to escape the unfavorable high-salt marine environment by adhering to (using adhesins) and penetrating (by the enzymes of ECP) the host tissue.

The SDS-PAGE revealed the appearance of two protein bands (approximately 35 and $70 \mathrm{kDa}$ ) specific to the ECP of the $3 \%-\mathrm{NaCl}$ culture. Suprapto et al. (1996) purified a lethal toxin from the ECP of E. tarda with a molecular weight of 37 $\mathrm{kDa}$. These bands seam to indicate proteins responsible for the toxicity of ECP.

The toxicity of the ECP of $V$. anguillarum to goldfish was established (Inamura et al., 1984). In the current study, injection of the same dose (19 $\mu \mathrm{g}$ protein/fish) of pooled ECP to goldfish demonstrated an obvious increase in the mortality rate in case of the $3 \%-\mathrm{NaCl}$ culture.

In conclusion, the stimulation of toxicity of E. tarda ECP by the high $\mathrm{NaCl}$ may be one of the pathogenic mechanisms utilized by the bacterium to establish the infection especially in the saltwater environment. Further investigations are still needed to elucidate the components of E. tarda ECP and their exact role in its pathogenicity.

\section{REFERENCES}

Badran, A.F. (1993): An outbreak of edwardsiellosis among Nile tilapia (Oreochromis niloticus) reared in pond supplied with domestic wastewater. Zagazig Vet. J. 21: 771-777.

Bradford, M.M. (1976): A rapid and sensitive method for the quantitation of microgram quantities of protein utilizing the principle of protein-dye binding. Anal. Biochem. 72: $248-254$.

Evance, J.J.; Klesius, P.H.; Plumb, J.A. and Shoemaker, C.A. (2011): Edwardsiella septicaemias. In "Fish diseases and disorders" (ed. by P.K. Woo and D.W. Bruno). CABI, London, pp. 512-569.

Farto, R.; Armada, S.P.; Montes, M.M.; Perez, J. and Nieto, T.P. (2006): Presence of a lethal protease in the extracellular products of Vibrio splendidus-Vibrio lentus related strains. J. Fish Dis. 29: 701-707.

Galal, N.F.; Ismail, S.G.; Khalil, M.R.H. and Soliman, M.K. (2005): Studies on Edwardsiella infection in Oreochromis niloticus. Egypt. J. Aquat. Res. 31: 460-471

Gudmundsdóttir, S. and Gudmundsdóttir, $B$. (2001): Induction of inflammatory cytokines by extracellular products and LPS of the fish pathogen Aeromonas salmonicida ssp. Achromogenes in mice and mouse cell cultures. Vet. Immunol. Immunopathol. 81: 71-83.

Han, H.J.; Kim, D.H.; Lee, D.C.; Kim, S.M. and Park, S.I. (2006): Pathogenicity of Edwardsiella tarda to olive flounder, Paralichthys olivaceus (Temminck and Schlegel). J. Fish Dis. 29: 601-609.

Ibrahem, M.D.; Shaheed, B.I.; Abo El-Yazeed, B.H. and Korani, H. (2011): Assessment of the susceptibility of polyculture reared African Catfish and Nile tilapia to Edwardsiella tarda. J. Am. Sci. 7(3): 779-786.

Inamura, H.; Muroga, K. and Nakai, T. (1984): Toxicity of extracellular products of Vibrio anguillarum. Fish Pathol. 19: 89-96.

Khalil; A.H. and Mansour, E.H. (1997): Toxicity of crude extracellular products of Aeromonas hydrophila in tilapia, Tilapia nilotica. Lett. Appl. Microbiol. 25: 269-273.

Laemmli, U.K. (1970): Cleavage of structural proteins during the assembly of the head of bacteriophage T4. Nature. 227: 680-685.

Leung, K.Y.; Siame, B.P.; Tenkink, B.J.; Noort, R.J. and Mok, Y.K. (2012): Edwardsiella tardaVirulence mechanisms of an emerging gastroenteritis pathogen. Microbes Infect. 14: 26-34.

Ling, S.H.; Wang, X.H.; Xie, L.; Lim, T.M. and Leung, K.Y. (2000): Use of green 
fluorescent protein (GFP) to study the invasion pathways of Edwardsiella tarda in in vivo and in vitro fish models. Microbilol. 146: 7-19.

Liu, P.V. (1957): Survey of hemolysin production among species of Pseudomonas. J. Bacteriol. 74: 718-727.

Mahmoud, M.M.; Okuda, J. and Nakai, T. (2006): Sodium chloride-enhanced adherence of Edwardsiella tarda to HEp-2 cells. Fish Pathol. 41: 165-170.

Pérez, M.J.; Rodríguez, L.A. and Nieto, T.P. (1998): The acetylcholine-sterase ichthyotoxin is a common component in the extracellular products of Vibrionaceae strains. J. Appl. Microbiol. 84: 47-52.

Sirinivasa Rao, P.S.; Lim, T.M. and Leung, K.Y. (2001): Opsonized virulent Edwardsiella tarda strains are able to adhere to and survive and replicate within fish phagocytes but fail to stimulate reactive oxygen intermediates. Infec. Immun. 69: 5689-5697.
Suprapto, H.; Hara, T.; Nakai, T. and Muroga, K. (1996): Purification of a lethal toxin of Edwardsiellla tarda. Fish Pathol. 31: 203-207.

Suprapto, H.; Nakai, T. and Muroga, K. (1995): Toxicity of extracellular products and intracellular components of Edwardsiellla tarda in the Japanese eel and flounder. J. Aquat. Anim. Health. 7: 292-297.

Ullah, M.A. and Arai, T. (1983): Pathological activities of the naturally occuring strains of Edwardsiella tarda. Fish Pathol. 18: 65-70.

Wang, X.H.; Oon, H.L.; Ho, G.W.; Wong, W.S.; Lim, T.M. and Leung, K.Y. (1998): Internalization and cytotoxicity are important virulence mechanisms in vibriofish epithelial cell interactions. Microbiol. 144: 2987-3002.

Yasunobu, H.; Arikawa, Y.; Furutsuka-Uozumi, K.; Dombo, M.; Iida, T.; Mahmoud, M.M; Okuda, J. and Nakai, T. (2006): Induction of hemagglutinating activity of Edwardsiella tarda by sodium chloride. Fish Pathol. 41: 29-34.

\section{تأثير كلوريد الصوديوم على إنتاج وسمية المنتجات الخارجية لميكروب الإدواردسيلا تاردا \\ ابتسام سيل حسن ، محمود مصطفى محمود ، توشيهيرو ناكاى \\ Email: mahmoud88@hotmail.com}

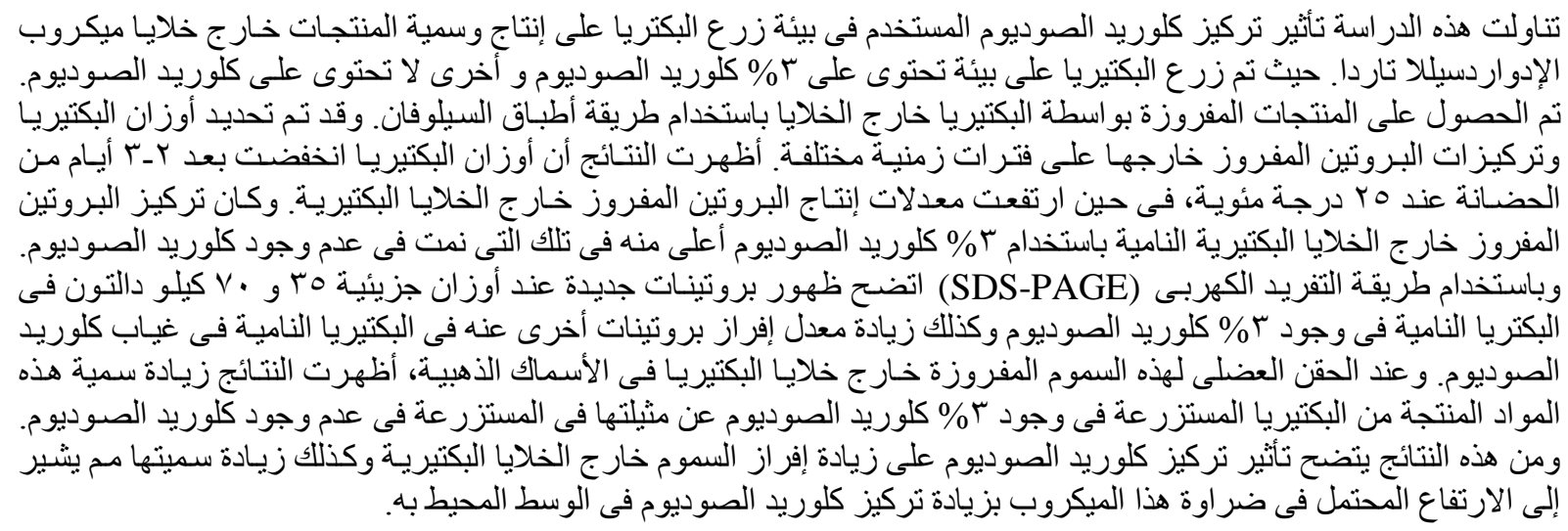

